\title{
Seasonal nutrient distribution in the Rupsha-Passur tidal river system of the Sundarbans mangrove forest, Bangladesh
}

Shak MB Rahaman ${ }^{1 *}$, Sudhin K Biswas ${ }^{1}$, Md S Rahaman², Alokesh K Ghosh', Lipton Sarder ${ }^{1}$, SMS Siraj ${ }^{1}$ and Sheikh S Islam'

\begin{abstract}
Introduction: The Rupsha-Passur River System (RS) is one of the biggest and important river systems in the Sundarbans estuarine ecosystem. It is the largest fresh water supplier into this mangrove forest. A comprehensive study was undertaken to evaluate the tidal and seasonal variations in nutrient concentrations (nitrate, phosphate, sulphate and ammonia) of the RS during October, 2010 (Post monsoon), February, 2011 (Dry winter) and August 2011 (Monsoon). In-situ measurement and laboratory analysis were conducted to measure nutrients and other physico-chemical parameters at discrete water layers of five study points under different tidal cycles.

Results: Following post monsoon, $\mathrm{NH}_{3}-\mathrm{N}$ concentration showed seasonal variation with increasing trend $(0.0703$ to $0.0803 \mathrm{mg} / \mathrm{L}$ ) in dry winter and then significant dropping $(0.013$ to $0.019 \mathrm{mg} / \mathrm{L})$ in monsoon period. During field observation, no significant tidal variation in ammonia concentration was identified among the study sites. Post monsoon and winter time observation recorded lower $\mathrm{SO}_{4}$ content ( 7.301 to $37.508 \mathrm{mg} / \mathrm{L}$ ) at all the sampling stations while in monsoon period, most of the stations showed higher concentration up to $126.92 \mathrm{mg} / \mathrm{L}$. Contrary to post monsoon season with comparatively higher $\mathrm{PO}_{4}-\mathrm{P}$ value $(0.314$ to $1.347 \mathrm{mg} / \mathrm{L})$, winter and monsoon period sampling indicated low phosphate concentrations $(0.045$ to $0.5 \mathrm{mg} / \mathrm{L}$ ) in the Rupsha-Passur RS. Most of the study sites showed considerable tidal changes in phosphate value during post monsoon and monsoon season while only two stations went through tidal fluctuation in sulphate content during monsoon period. Concentrations of $\mathrm{NO}_{3}-\mathrm{N}$ were found to fluctuate between 0.083 and $1.233 \mathrm{mg} / \mathrm{L}$ with no distinct seasonal distribution pattern. Tidal variation of $\mathrm{NO}_{3}-\mathrm{N}$ in the experimental sites was not so prominent during post monsoon period as of winter data.

Conclusion: Present study will serve as a basis for future hydrological and environmental studies in the world's largest Sundarbans intertidal mangrove forest. Study results indicate how nutrient dynamics of such diversified estuarine system are influenced by varying weather conditions. Daily fluctuations in nutrient concentrations and other physicochemical properties due to semidiurnal tidal activity were also figured out through the study. Information generated from the research works will guide all concerned for any future conservation and management initiatives for the world heritage site.
\end{abstract}

Keywords: Water quality; Monsoon; Aquatic; Ecosystem; Hydrodynamic environment; Post monsoon

\footnotetext{
* Correspondence: riti_rahaman@yahoo.com

${ }^{1}$ Fisheries and Marine Resource Technology Discipline, Khulna University, Khulna 9208, Bangladesh

Full list of author information is available at the end of the article
} 


\section{Introduction}

The Sundarbans forest is the largest continuous productive mangrove wetland ecosystem in the world (Rahaman et al. 2013). It is located at the extreme end of the southern Ganges delta, and it is about $10,000 \mathrm{~km}^{2}$ in southwest Bangladesh and West Bengal of India. A total area of $62 \%$ lies in the Khulna region of the southwestern part of Bangladesh, while the remaining $38 \%$ is in India (Siddiqi 2001). The Bangladesh portion of Sundarbans covers an area of $6,017 \mathrm{~km}^{2}$ of mangrove forests, wildlife sanctuaries, and sand bars, and out of this, $1,874 \mathrm{~km}^{2}$ is made up of rivers, creeks, and canals (Wahid 1995). It is a region of transition between the freshwater of the rivers originating from the Ganges and the saline water of the Bay of Bengal. The coast of the Sundarbans is crisscrossed by a network of complex estuarine system created by rivers Rupsha, Passur, Shibsha, Baleswar, Bhola, Arpangashia, Kholpetua, and other rivers which open into the Bay of Bengal through the Sundarbans reserved forest and carry large amounts of nutrients that vary with tides and seasons which facilitate the productivity in the area (Rahaman et al. 2013).

The mangrove forest of Bangladesh is one of the most important coastal features of the country. The existence of the mangrove has increased the values of other coastal and marine resources such as the coastal and marine fisheries by increasing productivity and supporting a wide biological diversity. The artisanal fishery, which is highly influenced by mangroves, has been contributing $85 \%$ to $95 \%$ of the total coastal and marine catch of Bangladesh. The mangrove also supports offshore and deep sea fisheries by playing a significant role as nursery ground for many deep sea fishes and shrimps including the giant tiger shrimp (Penaeusmonodon) which is the major species of the industrial bottom trawl fishery of Bangladesh. The mangrove also contributes significantly to shrimp farming which has been the most significant export-oriented industry since the 1970s.

Estuaries are an important segment of the biogeochemical cycle as they regulate the amount of river-borne major and minor elements entering the coastal environment and ultimately the deep ocean. Estuarine ecosystems are complex and dynamic due to strong gradients in the chemical composition of water, variable suspended matter concentration, and complex hydrodynamic processes. When river water mixes with seawater, different types of physical and chemical processes take place that may affect the partitioning of trace metals between particulate and dissolved phases and hence the composition of the deposited sediments (Forstner and Gnaiger 1983).

Today, the Sundarbans is entirely surrounded and pressured to the landward side as an island by human communities and their agricultural and commercial activities. Coastal polders have been commissioned since 1968 in the immediate upstream catchments to enhance agricultural productive potential of the land by protecting it from saline intrusion. However, the operation and maintenance cost of the polders are very high and most of them are in very bad condition impeding natural drainage of freshwater into western Sundarbans (PDO-ICZMP 2005). Industrial activity near the upstream river system (RS) as well as the nearby second largest seaport has expanded. Recently, the importance of estuarine processes in modifying the chemistry of the materials accumulating and passing through this interface has been realized. Several geochemical processes, such as precipitation and flocculation of the dissolved and colloidal substances (Coonley et al. 1971; Sholkovitz 1976; Gobeil et al. 1981) desorption-adsorption phenomenon, chemical diagenesis, and exchange with the bottom sediments (Yeats and Bewers 1982), have been studied within the mixing zone.

Passur river of the Sundarbans has influenced the Bhairab and is connected with the Garai-Madhumati system through Atarabanki and Nabaganga rivers. The Garai-Madhumati is the major spill river of the Ganges and carries out $12 \%$ of flow of the Ganges (Hussain and Acharya 1994). The Rupsha-Passur RS flows through the middle part of the Sundarbans mangrove forest and serves as the lifeline for millions of people inhabiting the mangrove-dominated Sundarbans and for different types of industries - agricultural land, fish farm, and shrimp farm - which are situated on the banks of the Rupsha river. A considerable quantity of toxic and hazardous substance is released into this important aquatic system through these industrial effluents along with huge organic load emanating from agricultural and shrimp culture activities and several non-point sources (such as discharges from fishing vessels and trawlers and runoff from adjacent landmasses).

The mangrove ecosystems are considered to have high primary productivity due to the nutrient enrichment and thus offer ideal fishing grounds. Nutrients are essential chemicals for the survival and growth of plants. A total of 20 elements are required for phytoplankton growth. These are C, H, O, N, P, S, K, Mg, Ca, Na, Fe, Mn, Cu, $\mathrm{Zn}, \mathrm{Mo}, \mathrm{V}, \mathrm{B}, \mathrm{Cl}, \mathrm{Co}$, and Si (Moss 1980). The most common and major nutrients are the compounds of nitrogen and phosphorus (Nybakken 1982). Dissolved organic and inorganic nutrients are found in aquatic environment at all times, and some of them are recycled naturally by decaying living organisms. Aqueous life depends on the availability of dissolved nitrogen and phosphorus (Skinner and Turekian 1973).

Harris (1986) reported that in an aquatic ecosystem, dissolved inorganic nitrogen such as ammonium, nitrate, nitrite, molecular $\mathrm{N}_{2}$ and DIN are therefore very much dependent on biological uptake and regeneration. It is estimated that nearly $95 \%$ of the $\mathrm{N}$ in the coastal environment is present as molecular $\mathrm{N}_{2}$. Dissolved nitrate $\left(\mathrm{NO}_{3}^{-}\right)$, nitrite $\left(\mathrm{NO}_{2}^{-}\right)$, and ammonium $\left(\mathrm{NH}_{4}^{+}\right)$ions are the 
three major sources of nitrogen, which are required by phytoplankton (Boney 1983). On the other hand, dissolved orthophosphate is another important nutrient source for phytoplankton as it is taken rapidly by phosphorusdeficient cells from water bodies with lower concentrations (Boney 1983). Low availability of phosphate in the freshwater environment could be one of the several factors which may cause a decline in primary productivity (Abel 1996; Law et al. 2001a), while the productivity in coastal waters is normally limited by the concentration of nitrogen compounds (Skinner and Turekian 1973).

Excess concentrations of nutrients that enter the aquatic ecosystem in the form of sewage and industrial wastes or runoff from urban areas can dramatically increase the primary productivity of the ecosystem, and this consequently may affect the marine water quality (Abel 1996). The source of additional organic and inorganic phosphate is mainly through discharges of domestic sewage, partly supplied by human waste and mainly from the use of phosphate-rich detergents and fertilizers (Abel 1996). Inorganic compounds such as ammonium are used preferentially by plants and produced by bacterial breakdown of organic matter and animal excretion. At optimal concentration, this nutrient concentration stimulated excess algal growth in unpolluted marine waters: ammonium concentrations are low and variable, nitrate that is an important source of nitrogen is present in large quantities, and nitrite is present in much lower quantities (Boney 1983). In polluted waters, it is known that high concentrations of nitrogen, particularly in the form of $\mathrm{NH}_{4}^{+}, \mathrm{NO}_{2}^{-}$, and $\mathrm{NO}_{3}^{-}$, can be toxic to many varieties of aquatic organisms and can constitute a human health hazard. Despite huge potential of this mangrove forest, very few attempts have been undertaken to investigate its soil and water properties especially the nutrient dynamics of this resourceful water body. The present study has been made to quantify some major nutrients at different locations and discrete water layers of the Rupsha-Passur RS under varying tidal and weather conditions.

\section{Methods}

\section{Study area}

The present study was conducted on the Rupsha-Passur RS which is in the middle part of the Sundarbans (polyhaline zone) of Bangladesh and is connected with the Garai-Madhumati RS through Atarabanki and Nabaganga rivers. The total length of the study area is about $15.71 \mathrm{~km}$, and water depth varies between 4.0 and $9.1 \mathrm{~m}$. Five sampling stations, namely, Karamjal, Karamjal Canal, Joymoni, Harbaria, and Harbaria Canal, were selected at the middle of the river and river-canal meeting places (Table 1 and Figure 1). Field observations were carried out in October 2010 (post monsoon), February 2011 (dry winter), and August 2011 (monsoon).

\section{Sampling}

For in situ measurement and laboratory analysis, water samples were collected from three different depths (surface, middle, and $0.5 \mathrm{~m}$ above the bottom) of the study points under three distinct seasons. In order to analyze tidal variations, water samples were collected both during high and low tide conditions. Three samples were taken from each water layer both during high and low tide under each season which makes a total of 270 samples for the whole observation. For each sampling season, 90 water samples were collected and carried to the laboratory for analyzing a variety of water parameters. A Ruttner water sampler and DO sampler were used with marked ropes to collect samples from varying depths of water. After collection of water sample, it was poured into $250-\mathrm{mL}$ plastic bottles and immediately preserved in an icebox and carried to the laboratory for nutrient analysis. During in situ measurement, salinity was recorded by an Atago S/Mill-E refractometer (Atago Co. Ltd., Tokyo, Japan), temperature by digital thermometer with stainless steel sensorprobe, $\mathrm{pH}$ by a Hanna microprocessor $\mathrm{pH}$ meter (model HI, $\mathrm{pH}$ 211; Hanna Instruments, Woonsocket, RI, USA), and dissolved oxygen (DO) by Winkler's method (APHA 1992).

\section{Laboratory analysis}

Collected water samples were analyzed in the laboratory for measuring concentrations of nitrate, ammonia, phosphate, and sulfate. A high-definition spectrophotometer was used for estimating the concentration of major water nutrients. During analysis, phosphate and sulfate were determined by the ascorbic acid method (Ramesh and Anbu 1996), while ammonia was measured by

Table 1 Geographical location of study areas and their water depth during sampling at different tides

\begin{tabular}{|c|c|c|c|c|}
\hline \multirow[t]{2}{*}{ Sampling station } & \multirow[t]{2}{*}{ Longitude } & \multirow[t]{2}{*}{ Latitude } & \multicolumn{2}{|c|}{ Water depth (m) } \\
\hline & & & Rising tide & Dropping tide \\
\hline Karamjal & $89^{\circ} 35^{\prime} 57.86^{\prime \prime} \mathrm{E}$ & $22^{\circ} 25^{\prime} 54.98^{\prime \prime} \mathrm{N}$ & 5.3 & 4.2 \\
\hline Karamjal Canal & $89^{\circ} 35^{\prime} 24.21^{\prime \prime} \mathrm{E}$ & $22^{\circ} 25^{\prime} 43.22^{\prime \prime} \mathrm{N}$ & 5.2 & 4.0 \\
\hline Joymoni & $89^{\circ} 37^{\prime} 49.65^{\prime \prime} \mathrm{E}$ & $22^{\circ} 20^{\prime} 51.35^{\prime \prime} \mathrm{N}$ & 7.0 & 5.9 \\
\hline Harbaria & $89^{\circ} 36^{\prime} 17.67^{\prime \prime} \mathrm{E}$ & $22^{\circ} 17^{\prime} 57.59^{\prime \prime} \mathrm{N}$ & 9.1 & 7.7 \\
\hline Harbarha Canal & $89^{\circ} 36^{\prime} 55.72^{\prime \prime} \mathrm{E}$ & $22^{\circ} 17^{\prime} 48.28^{\prime \prime} \mathrm{N}$ & 5.7 & 4.5 \\
\hline
\end{tabular}




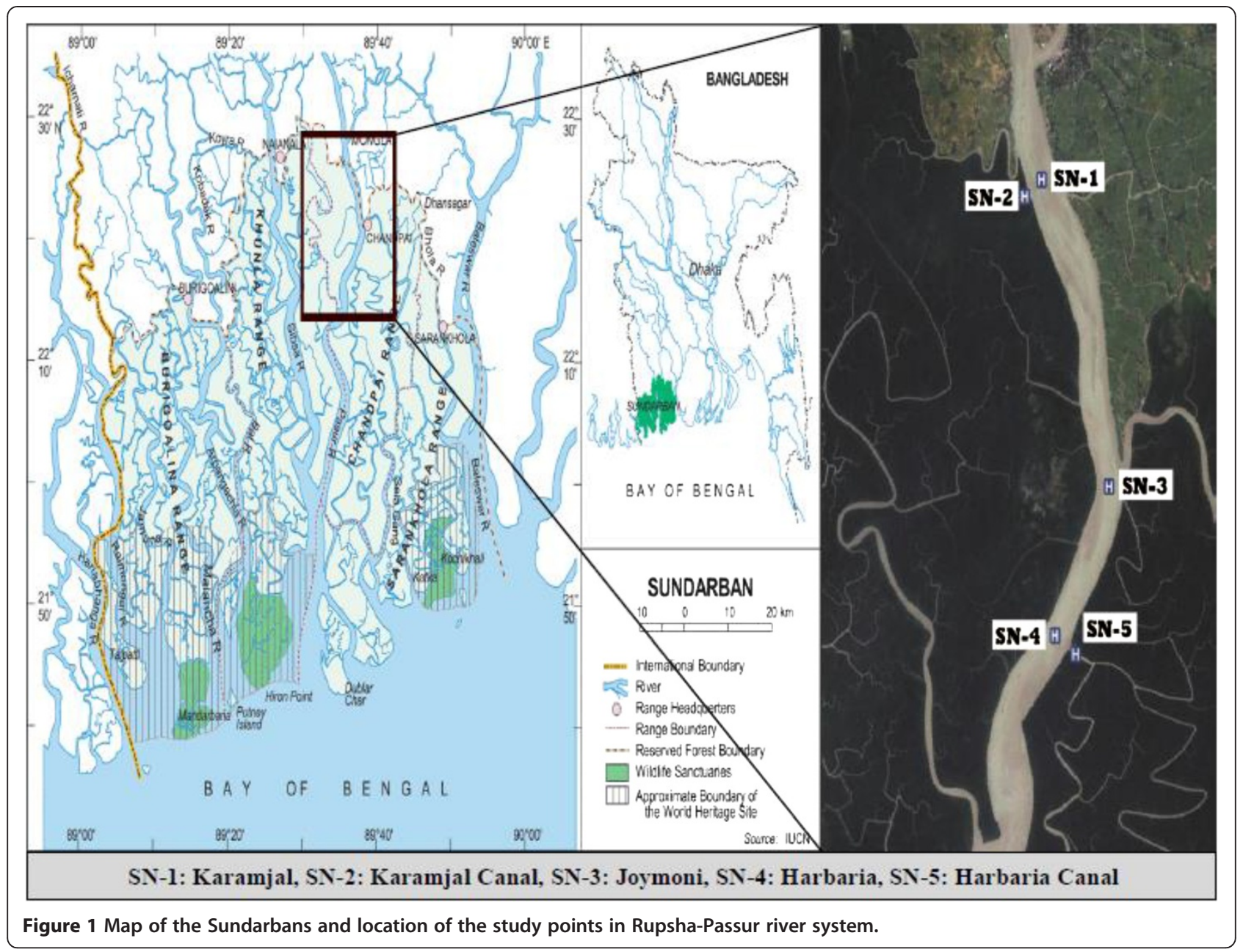

Nesslerization method (EPA Manual 1979) and nitrate was measured by phenol disulfonic acid method (Ramesh and Anbu 1996). Seasonal and tidal variations of nutrient concentrations were evaluated by calculating means and standard errors from the total number of samples taken for each analytic method during high and low tide within each sampling date.

\section{Statistical analyses}

Statistical comparison among means was performed by univariate analysis by SPSS software version 16.0 (SPSS Inc., Chicago, IL, USA).

\section{Results and discussion}

Status of physicochemical parameters Water temperature

Tidal and seasonal fluctuation of mean water temperature at the selected measuring points ranged from $19.23^{\circ} \mathrm{C}$ to $31.57^{\circ} \mathrm{C}$ with an average of $27.15^{\circ} \mathrm{C}$. Average temperature was found to be $29.37^{\circ} \mathrm{C}$ to $30.53^{\circ} \mathrm{C}$ during high tide and $28.8^{\circ} \mathrm{C}$ to $31.57^{\circ} \mathrm{C}$ during low tide in post monsoon, whereas in monsoon period, it was $29.8^{\circ} \mathrm{C}$ to $30.6^{\circ} \mathrm{C}$ during high tide and $30.9^{\circ} \mathrm{C}$ to $31.47^{\circ} \mathrm{C}$ at low tide. Field observation found an average temperature of $20.6^{\circ} \mathrm{C}$ to $21.67^{\circ} \mathrm{C}$ during rising tide, while $19.23^{\circ} \mathrm{C}$ to $21.4^{\circ} \mathrm{C}$ during dropping tide in dry winter. The tidal variation of temperature is found to be almost negligible but showed significant seasonal variation. Higher temperature was recorded both during monsoon and post monsoon seasons mostly at falling tide condition. Lower water temperature was observed during dry winter. Similar to the present study, Rahaman et al. (2013) and Hoq et al. (2002) found highest and lowest water temperature in the Sundarbans RSs during monsoon and winter seasons, respectively. The uniformity in water temperature values was due to high specific heat of the aquatic phase, which enables water to resist much fluctuation of temperature than the adjacent landmasses. The water temperature has considerable effect on phytoplankton population density by influencing the process of cyst germination (Ishikawa and Taniguchi 1994; Blanco 1995). Spatial and tidal uniformity in surface water temperature of the study area, however, has the least probability to affect the plankton community. Nutrient 
concentrations (nitrate, phosphate, and silicate) of aquatic system may be influenced when temperature rises as it affects the photosynthesis rate (Tait 1981; Pliński and Jóźwiak 1999).

\section{Water $\mathrm{pH}$}

The distribution of $\mathrm{pH}$ at different water depths of the Sundarbans mangrove RS under varying seasons and tidal cycles was varied. During post monsoon, mean $\mathrm{pH}$ ranged from 7.73 to 7.83 at high tide and from 7.77 to 7.97 at low tide. Dry winter showed water $\mathrm{pH}$ varying from 7.22 to 7.74 during high tide and from 7.34 to 7.89 at low tide condition. Rupsha-Passur RS indicated water $\mathrm{pH}$ to be 7.19 to 7.54 and 7.23 to 7.59 at high and low tide, respectively. During the study period, tidal and seasonal variations of water $\mathrm{pH}$ were not so significant. Rahaman et al. (2013) conducted field observations in the Kholpetua-Arpangashia $\mathrm{RS}$ and found higher $\mathrm{pH}$ values during winter when the tidal level was rising, whereas during post monsoon and monsoon seasons, the recorded $\mathrm{pH}$ values of most of the stations were a bit higher at low tide than at high tide. Hoq et al. (2006) reported that river water of the Sundarbans was characterized by slightly alkaline $\mathrm{pH}$ and water $\mathrm{pH}$ remains neutral to alkaline (7.4 to 8.1 ) throughout the study period. Generally, fluctuations in $\mathrm{pH}$ values can be attributed to factors like removal of $\mathrm{CO}_{2}$ by photosynthesis through bicarbonate degradation, dilution of seawater by freshwater influx, reduction of salinity and temperature, and decomposition of organic matter.

\section{Salinity}

Water salinity distribution pattern at the selected sampling stations of Rupsha-Passur RS is shown in Figure 2. During in situ measurement, salinity fluctuated between
6 to 10 ppt and 7 to 10 ppt at high and low tide, respectively, in post monsoon season (Figure 2). During dry winter, water salinity varied from 10 to $13 \mathrm{ppt}$ in high tide and from 10 to $11 \mathrm{ppt}$ in low tide, while monsoon data indicated 4 to $7 \mathrm{ppt}$ and 4 to $6 \mathrm{ppt}$ water salinity at rising and falling tide, respectively. Significant tidal variation of water salinity (Figure 2) in all the seasons along the river system is being regulated by the discharge of freshwater from the upstream. Mean water salinity was recorded as 10 and 14 ppt, 20.67 and 22.83 ppt, and 8.67 and 11.33 ppt during post monsoon, winter, and monsoon seasons, respectively, in the Kholpetua-Arpangashia RS (which is in the west and characterized by limited freshwater input from inland sources) of the Sundarbans (Rahaman et al. 2013). Higher level of salinity was recorded during high tide in dry season. Rahaman et al. (2013) and Hoq et al. (2006) indicated that the salinity of the Sundarbans RS steadily increases to reach its maximum in March following the monsoon and there is a decline from June to a minimum in the monsoon months (July to September). The authors also observed that water salinity of Passur and Shibsha rivers drops even below 1 ppt from August to November. The salinity values (mean of high tide and low tide) were found to be decreased from downstream to upstream zone. Study result shows significant spatial variation in water temperature. The discharge of freshwater by the upstream river is responsible for a decreasing trend in water salinity from upstream to downstream. During rising tide, water from the Bay of Bengal enters the present estuarine zone that contributes to a rising in salinity distribution pattern. However, at dropping tide condition, freshwater discharge from the upstream rivers gets salinity at lower level in the study area. Such variation in water salinity with tidal fluctuation was also documented by NEERI (1976), Mitra et al. (2011), and

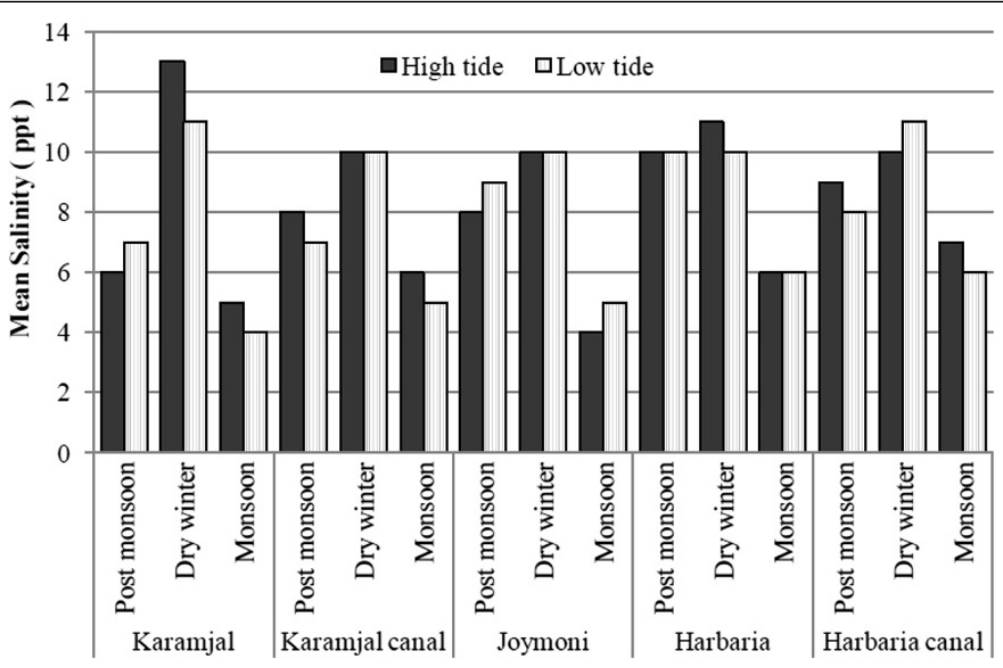

Figure 2 Variations in water salinity of the study points at high and low tide of different seasons. 


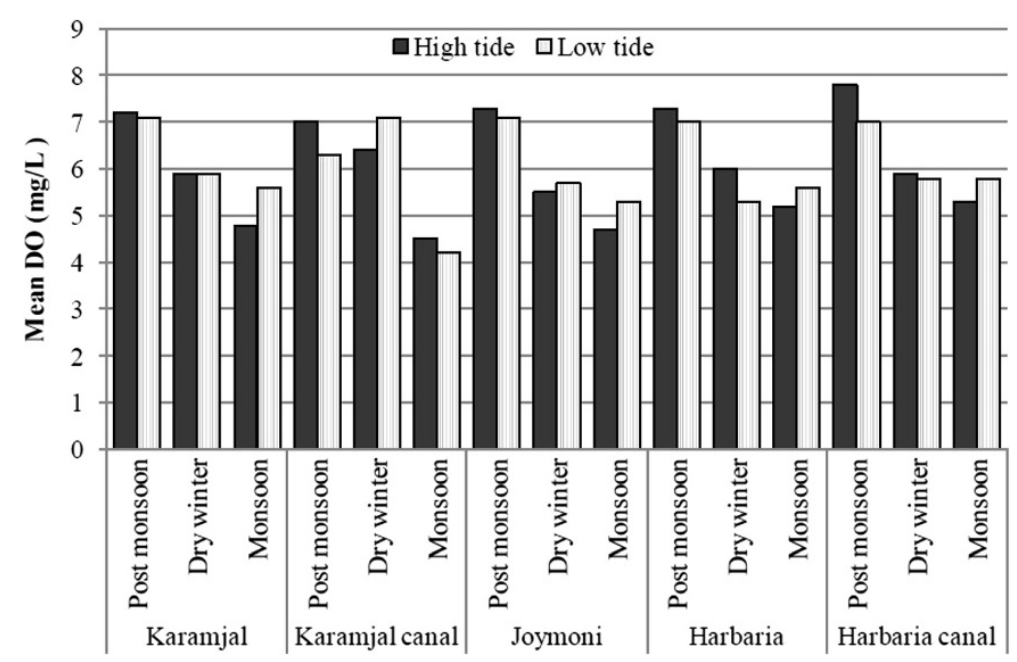

Figure 3 Seasonal and tidal fluctuation of DO at the study points.

Mukhopadhyay et al. (2006). Salinity distribution pattern in the Sundarbans mangrove forest is highly dependent on the volume of freshwater coming from the upstream and the nature of tide. Water salinity near the coast and inside the forest varies over a number of different timescales. Daily peak salinity at the coast generally coincides with the arrival of high water, whereas the daily range of salinity level varies with season.

\section{Dissolved oxygen}

Seasonal and tidal variations of DO at the experimental sites along with its distribution at the upper, middle, and bottom layers of the water body are shown in Figure 3. Rupsha-Passur RS indicated the concentration to be between 5.5 to $6.4 \mathrm{mg} / \mathrm{L}$ at high tide and 5.3 to $7.1 \mathrm{mg} / \mathrm{L}$ at low tide during dry winter season, whereas during monsoon, DO level fluctuated from 4.53 to $5.33 \mathrm{mg} / \mathrm{L}$ and from 4.2 to $5.8 \mathrm{mg} / \mathrm{L}$ at high and low tide, respectively. Post monsoon observation at the measuring stations recorded DO level to be between 7.0 to $7.8 \mathrm{mg} / \mathrm{L}$ and 6.27 to $7.13 \mathrm{mg} / \mathrm{L}$ at rising and dropping tide, respectively. Maximum and minimum concentration of DO was measured in post monsoon and monsoon periods, respectively. Rahaman et al. (2013) found higher concentrations of DO in post monsoon ( 4.37 to $7.03 \mathrm{mg} / \mathrm{L})$ and dry winter $(4.37$ to $6.23 \mathrm{mg} / \mathrm{L}$ ) seasons, whereas a lower DO concentration (3.90 to $4.63 \mathrm{mg} / \mathrm{L}$ ) was found during the monsoon period in the RS located at the far west of the present study area. Hoq et al. (2002) observed the highest DO content $(7.1 \mathrm{mg} / \mathrm{L})$ in the monsoon period and the lowest (4.9 $\mathrm{mg} / \mathrm{L})$ in the premonsoon period. The higher values of DO in the upstream stations may be due to DOenriched inland freshwater input through the river. Significant tidal variation in DO with relatively higher value during low tide period is the result of more freshwater input during this phase of the tidal cycle. The contributory role of fresh water to increase dissolved oxygen was supported by Nair (1985) while working in the Kalpakkam waters. The oxygen saturation concentration depends on temperature and salinity (Weiss 1970). In addition to these conservative parameters, the dissolved oxygen concentration depends on the photosynthetic rate and subsequently on nutrient concentrations. High temperature and salinity cause the oxygen to be relatively low (Badran 2001): the higher the temperature, the lower the solubility of oxygen in seawater.

\section{Distribution of nutrients}

\section{Nitrate}

Nitrate concentrations as $\mathrm{NO}_{3}-\mathrm{N}$ in the Rupsha-Passur RS were generally low and varied from 0.083 to $1.233 \mathrm{mg} / \mathrm{L}$ during high tide and from 0.313 to $0.7 \mathrm{mg} / \mathrm{L}$ during low tide in dry winter (Figure 4). During monsoon season, nitrate was measured as 0.631 to $0.960 \mathrm{mg} / \mathrm{L}$ and 0.700 to $0.960 \mathrm{mg} / \mathrm{L}$ at high and low tide conditions, respectively, while in the post monsoon period, it was 0.497 to $0.968 \mathrm{mg} / \mathrm{L}$ at high tide and 0.227 to $0.885 \mathrm{mg} / \mathrm{L}$ at low tide (Figure 4). For three distinct seasons and two tidal cycles, average concentration of nitrate was estimated to be $0.663 \mathrm{mg} / \mathrm{L}$. During the same study period, Rahaman et al. (2013) recorded mean $\mathrm{NO}_{3}-\mathrm{N}$ concentrations varying from 0.04 to $0.46 \mathrm{mg} / \mathrm{L}$ with an average of $0.15 \mathrm{mg} / \mathrm{L}$ in the Kholpetua-Arpangashia RS of the tidally influenced mangrove ecosystem. The highest and lowest concentrations of nitrate were found in the study area at the Joymoni and Harbaria Canal during the monsoon period and dry winter season, respectively. Mean values of nitrate at discrete water layers of the measuring points are shown in Table 2. The tidal variation of $\mathrm{NO}_{3}-\mathrm{N}$ showed an irregular distribution pattern. In this study, the highest 


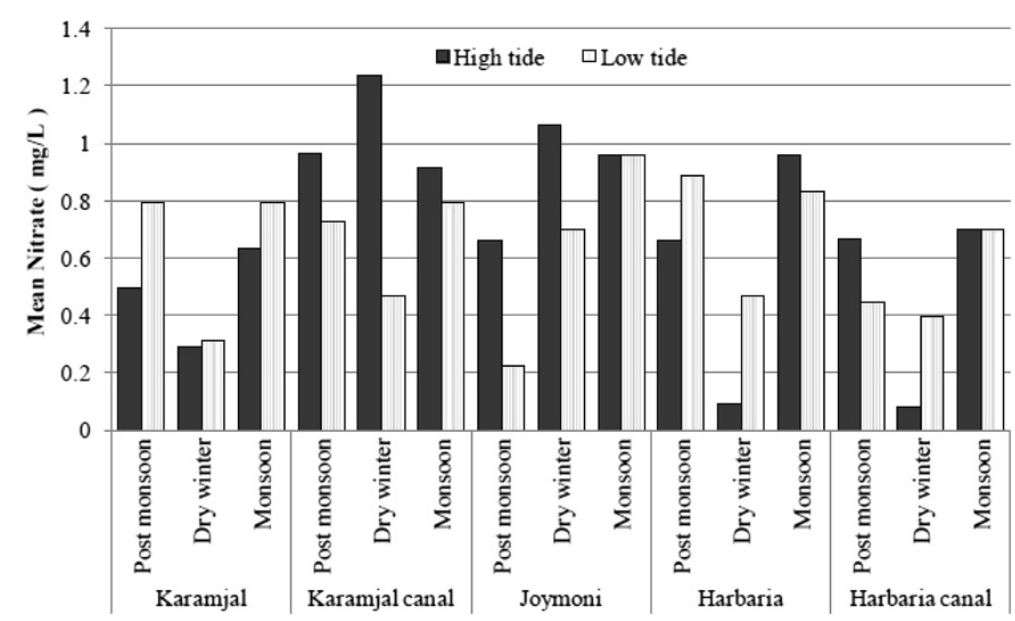

Figure 4 Nitrate concentrations at the experimental sites under different seasons and tidal cycles.

concentration was found during high tide in most seasons (Figure 4). The average concentration $(0.663 \mathrm{mg} / \mathrm{L})$ of $\mathrm{NO}_{3}-\mathrm{N}$ was lower than the environmental quality standard (EQS) in Bangladesh (10 mg/L) (DOE 1991). The irregular distribution of $\mathrm{NO}_{3}-\mathrm{N}$ during high tide can be the cause of continuous mixing of $\mathrm{N}_{2}$ between air and water taking place during high tide (Gribsholt et al. 2005). The present value is slightly higher than that of Wahid et al. (2007) who showed an average figure of $0.461 \mathrm{mg} / \mathrm{L}$ indicating little or no human intervention of the river system.

\section{Sulfate}

Sulfate is a major constituent of coastal water and is used as an electron acceptor for the oxidation of organic matter in the absence of oxygen. Table 2 shows the distribution of mean sulfate at the surface, middle, and bottom layers of selected stations. In the present study, mean sulfate values were recorded for the Rupsha-Passur RS to be between 21.08 and $37.51 \mathrm{mg} / \mathrm{L}$ during high tide and 22.55 and $30.47 \mathrm{mg} / \mathrm{L}$ during low tide in dry winter (Figure 5). During monsoon, sulfate concentration was measured as 7.56 to $126.92 \mathrm{mg} / \mathrm{L}$ and 12.48 to $122.26 \mathrm{mg} / \mathrm{L}$ at rising and dropping tide, respectively, while in post monsoon, high and low tide water showed concentrations ranging from 7.38 to $10.05 \mathrm{mg} / \mathrm{L}$ and from 7.30 to $8.42 \mathrm{mg} / \mathrm{L}$, respectively, with an average figure of $29.77 \mathrm{mg} / \mathrm{L}$ (Figure 5). The maximum amount of $\mathrm{SO}_{4}$ was detected in Harbaria station during monsoon, while minimum concentration

Table 2 Mean of surface, middle and bottom water layer nutrients measured at the study points under high and low tide conditions

\begin{tabular}{lccccc}
\hline Sampling station & Study period & $\mathbf{P O}_{\mathbf{4}}-\mathbf{P}(\mathbf{m g} / \mathbf{L})$ & $\mathbf{S O}_{\mathbf{4}}(\mathbf{m g} / \mathbf{L})$ & $\mathbf{N O}_{\mathbf{3}}-\mathbf{N}(\mathbf{m g} / \mathbf{L})$ & $\mathbf{N H} \mathbf{H}_{\mathbf{3}} \mathbf{- N}(\mathbf{m g} / \mathbf{L})$ \\
\hline Karamjal & Post monsoon & $0.533 \pm 0.226$ & $7.902 \pm 0.733$ & $0.646 \pm 0.210$ & $0.038 \pm 0.007$ \\
& Dry winter & $0.223 \pm 0.047$ & $30.144 \pm 0.466$ & $0.303 \pm 0.014$ & $0.075 \pm 0.002$ \\
Karamjal Canal & Monsoon & $0.314 \pm 0.263$ & $19.724 \pm 6.445$ & $0.713 \pm 0.116$ & $0.015 \pm 0.001$ \\
& Post monsoon & $0.492 \pm 0.252$ & $7.989 \pm 0.242$ & $0.848 \pm 0.168$ & $0.050 \pm 0$ \\
& Dry winter & $0.112 \pm 0.007$ & $21.819 \pm 1.039$ & $0.85 \pm 0.542$ & $0.075 \pm 0.007$ \\
Joymoni & Monsoon & $0.137 \pm 0.012$ & $51.065 \pm 53.33$ & $0.856 \pm 0.085$ & $0.015 \pm 0.003$ \\
& Post monsoon & $0.557 \pm 0.292$ & $7.674 \pm 0.141$ & $0.443 \pm 0.306$ & $0.047 \pm 0$ \\
& Dry winter & $0.262 \pm 0.106$ & $28.454 \pm 1.069$ & $0.883 \pm 0.259$ & $0.077 \pm 0$ \\
Harbaria & Monsoon & $0.127 \pm 0.098$ & $13.697 \pm 1.710$ & $0.96 \pm 0$ & $0.014 \pm 0.00$ \\
& Post monsoon & $0.410 \pm 0.042$ & $7.819 \pm 0.733$ & $0.772 \pm 0.159$ & $0.040 \pm 0$ \\
& Dry winter & $0.162 \pm 0.077$ & $32.451 \pm 7.151$ & $0.28 \pm 0.264$ & $0.077 \pm 0$ \\
Harbaria Canal & Monsoon & $0.166 \pm 0.171$ & $64.911 \pm 81.103$ & $0.895 \pm 0.091$ & $0.016 \pm 0.002$ \\
& Post monsoon & $0.892 \pm 0.643$ & $8.742 \pm 1.854$ & $0.556 \pm 0.158$ & $0.050 \pm 0.004$ \\
& Dry winter & $0.163 \pm 0.127$ & $24.434 \pm 2.653$ & $0.24 \pm 0.221$ & $0.073 \pm 0.004$ \\
& Monsoon & $0.289 \pm 0.205$ & $119.75 \pm 10.139$ & $0.7 \pm 0$ & $0.017 \pm 0.002$ \\
\hline
\end{tabular}




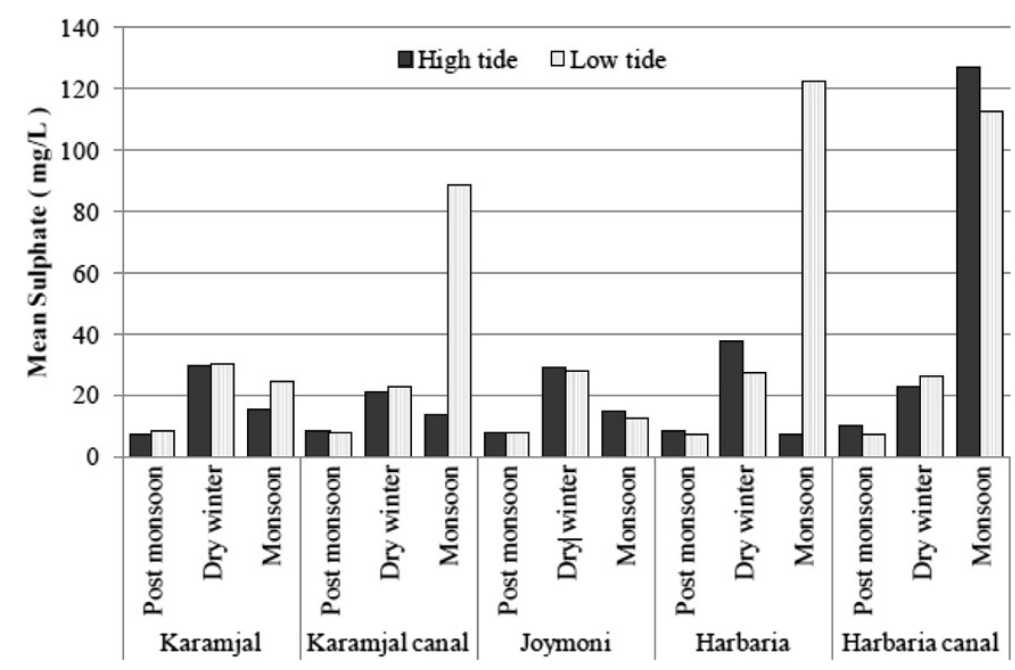

Figure 5 Distribution of sulfate at different study points under varying seasons and tidal conditions.

was observed in post monsoon season with a rising pattern from upstream to downstream. The westernmost RS showed $\mathrm{SO}_{4}$ concentrations between 58.71 and $136.47 \mathrm{mg} / \mathrm{L}$ with an average of $95.69 \mathrm{mg} / \mathrm{L}$, and the lowest and highest concentrations during the post monsoon and monsoon periods, respectively (Rahaman et al. 2013). The average $\mathrm{SO}_{4}$ concentration $(29.77 \mathrm{mg} / \mathrm{L})$ indicates the presence of available sulfate in the water body. Study results show significant spatial and tidal variations of dissolved sulfate in few locations of the Rupsha-Passur RS of the Sundarbans intertidal mangrove forest. Field observations exhibited a higher concentration of sulfate in the downstream stations under the influence of seawater mixing. The relatively lower concentration of sulfate in the upper estuarine stretch may be due to consumption of the anion by paddy fields along the upstream stations, whereas removal is compensated in the lower part of the estuary by the contribution of seawater and decay of organic matter from mangroves. Ramanathan et al. (1993) came up with similar observations and reported that seawater input along with resuspension mixing (turbidity and mixing) of decayed organic matter and oxidation of buried biogenic materials results in enhanced sulfate levels in mangrove waters. The sulfate value is generally higher during high tide in monsoon due to the intrusion of river runoff from upstream land. Study results also indicated that salinity and sulfate values do not reflect each other. Sulfate values should be much higher in the study area if we go by the reported salinity values (Figure 6). Figure 6 shows that there was no strict relation between these two variables.

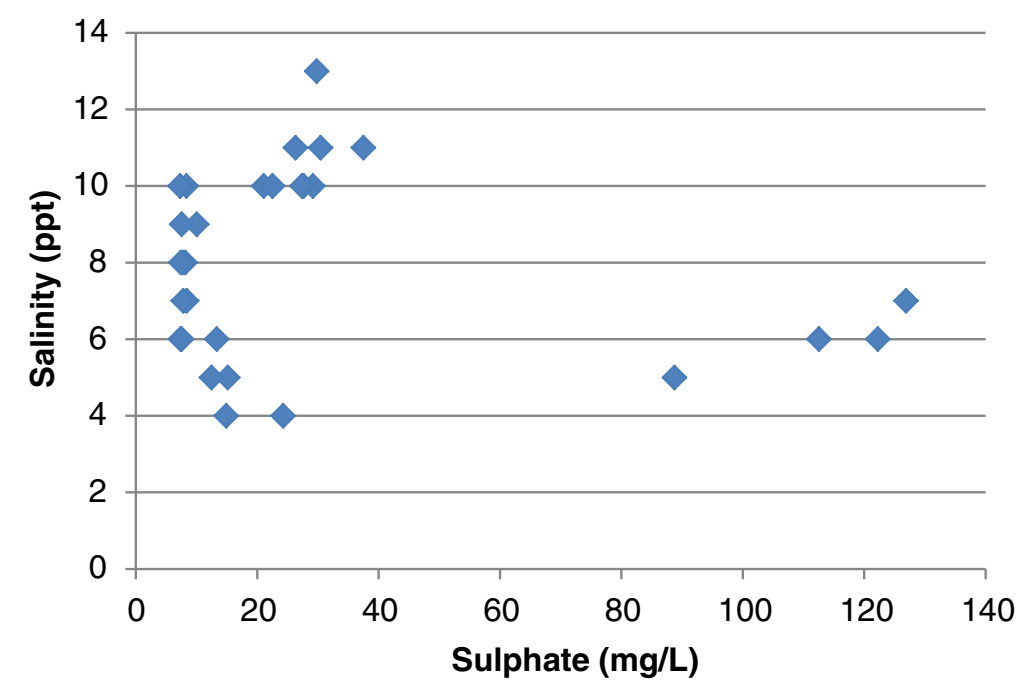

Figure 6 Relation between salinity and sulfate during high tide and low tide in different seasons. 


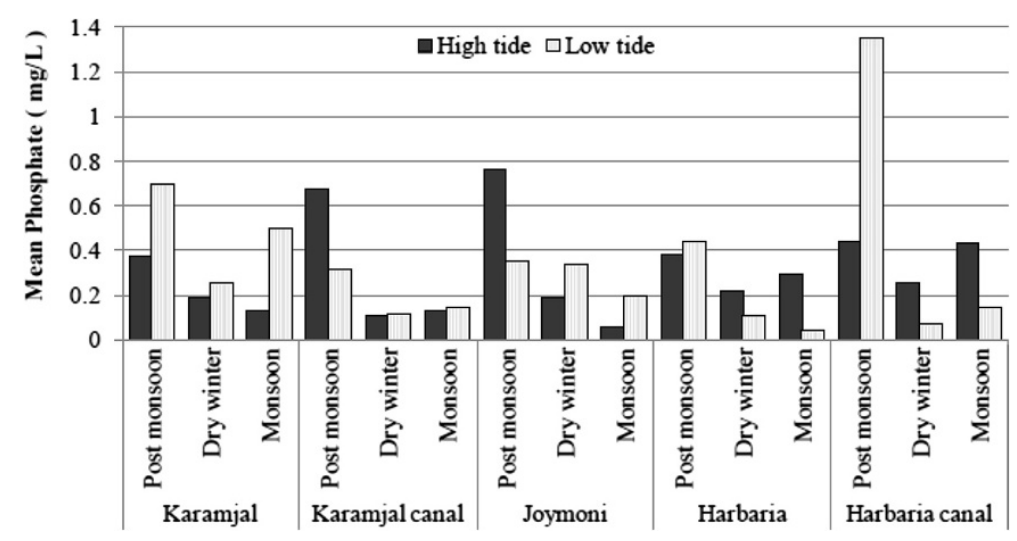

Figure 7 Tidal and seasonal distribution of phosphate at the measuring stations.

\section{Phosphate}

Phosphate concentration at three water layers of the experimental sites is presented in Table 2. The study result shows lower concentration of phosphate as $\mathrm{PO}_{4}-\mathrm{P}$ at the measuring stations, ranging from 0.107 to $0.254 \mathrm{mg} / \mathrm{L}$ during rising tide and from 0.073 to $0.337 \mathrm{mg} / \mathrm{L}$ at low tide in dry winter (Figure 7). During monsoon, phosphate distribution varies from 0.057 to $0.435 \mathrm{mg} / \mathrm{L}$ and from 0.045 to $0.500 \mathrm{mg} / \mathrm{L}$ at high and low tide, respectively, while in post monsoon, the concentration remained between 0.374 to $0.764 \mathrm{mg} / \mathrm{L}$ during high tide and 0.314 to $1.347 \mathrm{mg} / \mathrm{L}$ during low tide (Figure 7). Comparatively higher concentration of $\mathrm{PO}_{4}-\mathrm{P}$ was detected at few stations of the study area. Rahaman et al. (2013) also observed lower mean phosphate values ranging from 0.05 to $0.42 \mathrm{mg} / \mathrm{L}$ with an average of $0.12 \mathrm{mg} / \mathrm{L}$ at different tidal cycles over three sampling seasons in that area. The average value of $\mathrm{PO}_{4}-\mathrm{P}$ was recorded as $0.323 \mathrm{mg} / \mathrm{L}$ which is higher than Wahid et al. (2007) who measured average concentration as $0.115 \mathrm{mg} / \mathrm{L}$.
IWM (2003) mentioned relatively low concentration of phosphate $(0.009$ to $0.582 \mathrm{mg} / \mathrm{L})$ which averages to $0.115 \mathrm{mg} / \mathrm{L}$.

\section{Ammonia}

Figure 8 and Table 2 show the distribution of mean ammonia at several experimental sites under different tidal cycles and weather conditions. The concentration of $\mathrm{NH}_{3}-\mathrm{N}$ was found to vary between 0.077 to $0.080 \mathrm{mg} / \mathrm{L}$ during high tide and 0.070 to $0.077 \mathrm{mg} / \mathrm{L}$ during low tide in dry winter season. Monsoon observation recorded ammonia concentration ranging from 0.013 to $0.018 \mathrm{mg} / \mathrm{L}$ during high tide and 0.014 to $0.019 \mathrm{mg} / \mathrm{L}$ during low tide condition, while in post monsoon, 0.034 to $0.054 \mathrm{mg} / \mathrm{L}$ and 0.040 to $0.050 \mathrm{mg} / \mathrm{L}$ ammonia were measured in the Rupsha-Passur RS during rising and falling tide, respectively. During field observation, average concentration of ammonia was detected as $0.045 \mathrm{mg} / \mathrm{L}$. Higher concentration of $\mathrm{NH}_{3}-\mathrm{N}$ was found in winter season, while in monsoon, the concentration was much lower

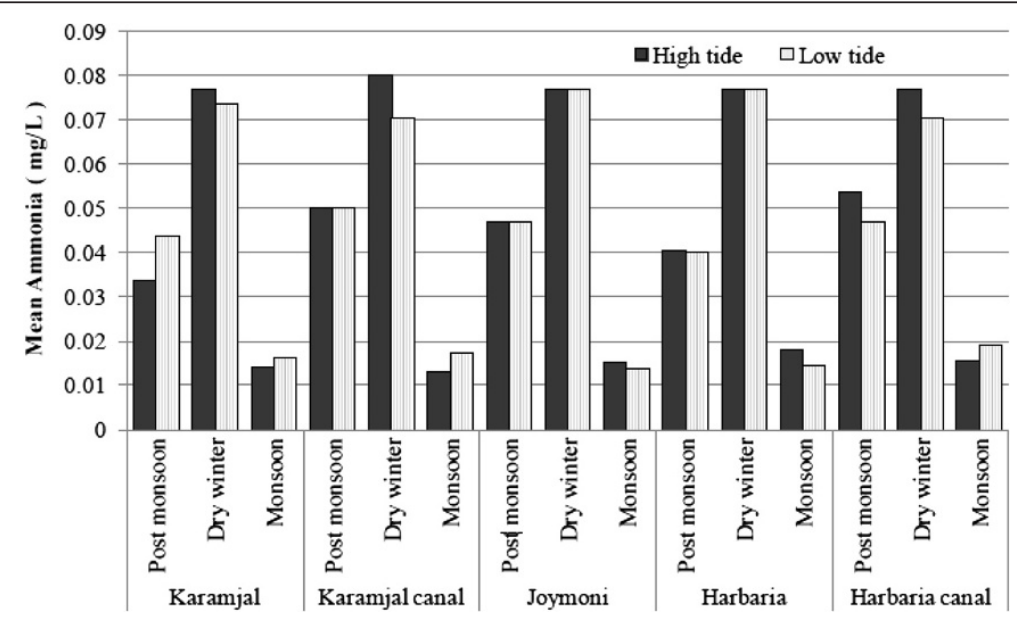

Figure 8 Ammonia distribution in the study area at high and low tide during sampling seasons. 
Table 3 The coefficient of correlation of different water quality parameters

\begin{tabular}{lccc}
\hline Serial no. & Particulars & $\begin{array}{c}\text { Coefficient of } \\
\text { correlation }\end{array}$ & Comments \\
\hline 1. & Temperature vs nitrate & 0.387 & Significant \\
2. & Temperature vs ammonia & -0.867 & Inversely related \\
3. & Temperature vs phosphate & 0.296 & Significant \\
4. & Temperature vs sulfate & 0.094 & Less significant \\
5. & pH vs ammonia & 0.193 & Significant \\
6. & pH vs nitrate & -0.194 & Inversely related \\
7. & pH vs phosphate & 0.482 & Significant \\
8. & pH vs sulfate & -0.342 & Inversely related \\
9. & DO vs ammonia & 0.356 & Significant \\
10 & DO vs nitrate & -0.208 & Inversely related \\
11. & DO vs phosphate & 0.549 & Significant \\
12. & DO vs sulfate & -0.398 & Inversely related \\
13. & Salinity vs ammonia & 0.891 & Significant \\
14. & Salinity vs nitrate & -0.482 & Inversely related \\
15. & Salinity vs phosphate & -0.023 & Less inversely \\
& & & related \\
16. & Salinity vs sulfate & -0.185 & Inversely related \\
\hline
\end{tabular}

than in post monsoon. The same study periods indicated mean NH3-N concentrations for western locations of the Sundarbans ranging from 0.02 to $0.38 \mathrm{mg} / \mathrm{L}$ with an average of $0.14 \mathrm{mg} / \mathrm{L}$ (Rahaman et al. 2013). The authors found higher concentrations during monsoon but relatively lower values during post monsoon and winter periods. $\mathrm{NH}_{3}-\mathrm{N}$ distribution showed a distinct seasonal variation with a rising trend from post monsoon to winter and then significant dropping in monsoon. The presence of nonionized ammonia $\left(\mathrm{NH}_{3}-\mathrm{N}\right)$ in very low proportion (an average of $0.045 \mathrm{mg} / \mathrm{L}$ ) is an indication of good quality river water with respect to ammoniacal nitrogen inside the Sundarbans aquatic ecosystem. The observed values of ammonia are slightly lower than those in Wahid et al. (2007) where average concentration is mentioned to be $0.054 \mathrm{mg} / \mathrm{L}$. IWM (2003) recorded ammonia content to be between 0.001 and $0.33 \mathrm{mg} / \mathrm{L}$ with an average figure of $0.043 \mathrm{mg} / \mathrm{L}$ which is very close to the present study results.

\section{Relationships among physicochemical parameters and nutrient constituents}

The relationships among different parameters are shown in Table 3. Temperature was positively correlated with nitrate and phosphate but was negatively related with ammonia. $\mathrm{pH}$ had a positive relation with ammonia and phosphate but had a negative relationship with nitrate and sulfate. DO had a positive correlation with ammonia and phosphate but had a negative relation with nitrate and sulfate. Salinity had a negative relationship with nitrate, phosphate, and sulfate but had a positive relationship with ammonia. Temperature has a direct negative effect on the oxygen saturation of the water and shifts the chemical balance of reduced nitrogen towards toxic $\mathrm{NH}_{3}$. Both temperature and $\mathrm{pH}$ increase the $\mathrm{NH}_{3}$ concentration (Emerson et al. 1975). Ammonia-nitrogen $\left(\mathrm{NH}_{3}-\mathrm{N}\right)$ has a more toxic form at high $\mathrm{pH}$ and a less toxic form at low $\mathrm{pH}$, un-ionized ammonia $\left(\mathrm{NH}_{3}\right)$ and ionized ammonia $\left(\mathrm{NH}_{4}^{+}\right)$, respectively. In addition, ammonia toxicity increases as temperature rises (William 2002).

\section{Conclusions}

The Sundarbans mangrove wetland forest serves as a link between terrestrial and marine ecosystems. The study provides comprehensive seasonal, tidal, and spatial characterization of hydrological regime of the Sundarbans estuarine ecosystem of Bangladesh. With the onset of monsoon, the central part of the Sundarbans experiences the greatest reduction in salinity level. Augmentation of the freshwater inflow from the upstream reduces the salinity in the Rupsha-Passur river system. The major nutrients showed significant seasonal changes in concentration level, and in few cases, considerable tidal variations were also observed. Concentrations of $\mathrm{NO}_{3}-\mathrm{N}$ were found to vary between 0.083 and $1.233 \mathrm{mg} / \mathrm{L}$ with an average figure of $0.663 \mathrm{mg} / \mathrm{L}$ and no distinct seasonal distribution pattern. Phosphate concentrations as $\mathrm{PO}_{4}-\mathrm{P}$ were generally low $(0.045$ to $0.5 \mathrm{mg} / \mathrm{L})$ in dry winter and monsoon, whereas post monsoon season showed comparatively higher content of phosphate $(0.314$ to $1.347 \mathrm{mg} / \mathrm{L})$ in the Rupsha-Passur RS. The present study observed lower $\mathrm{SO}_{4}$ content (7.301 to $37.508 \mathrm{mg} / \mathrm{L}$ ) at all the sampling stations over post monsoon and winter seasons, while most of the stations showed higher concentration (up to $126.92 \mathrm{mg} / \mathrm{L}$ ) during monsoon. Ammonia distribution showed significant variation with 0.026 to $0.047 \mathrm{mg} / \mathrm{L}$ in post monsoon season, then higher content (0.0703 to $0.0803 \mathrm{mg} / \mathrm{L}$ ) during dry winter and lowest concentration of $0.013 \mathrm{mg} / \mathrm{L}$ in monsoon season. Thus, the major nutrients of the Sundarbans mangrove forest RS is regulated by seasonal variations, and in most cases, little impact comes from tidal fluctuation.

\section{Competing interests}

The authors declare that they have no competing interests.

\section{Authors' contributions}

SMBR formulated the research concept, developed and implemented the project, coordinated field measurements, collected and processed the samples, facilitated the laboratory analysis, analyzed and interpreted the data, drafted and revised the manuscript, and gave final approval of the version to be published. SKB performed the in situ measurement and laboratory analysis of water quality parameters, data entry, analysis and summary, and initial setup of the manuscript. MSR implemented the research works and coordinated the in situ measurement and laboratory analysis of water 
samples. AKG analyzed and summarized the data, and drafted and revised the research article. LS performed the in situ measurement and laboratory analysis, acquired the data, and analyzed the data. SMSS performed the in situ measurement and laboratory analysis. SSI revised the manuscript. All authors read and approved the final manuscript.

\section{Acknowledgements}

The authors would like to acknowledge the financial support of the Ministry of Education, Bangladesh for successful implementation of the research project. The Bangladesh Forest Department offered all the required supports during in situ measurement and sample collection from the river system. We are thankful to the laboratory staffs of Fisheries and Marine Resource Technology Discipline, Khulna University for their efforts and cooperation during sample analysis. Two anonymous reviewers are appreciated for their valuable comments and suggestions.

\section{Author details}

${ }^{1}$ Fisheries and Marine Resource Technology Discipline, Khulna University, Khulna 9208, Bangladesh. ${ }^{2}$ Chemistry Department, Comilla University, Comilla 3500, Bangladesh.

Received: 29 March 2014 Accepted: 3 July 2014

Published online: 29 July 2014

\section{References}

Abel PD (1996) Water pollution biology, 2nd edn. CRC Press, UK Taylor \& Francis Ltd, 11 New Fetter Lane, London, EC4P 4EE USA Taylor \& Francis Inc., 325 Chestnut Street, 8th Floor, Philadelphia, DA 19106 p 296

APHA (1992) Standard methods for the examination of water and wastewater, 18th edn. American Public Health Association, Washington, DC

Badran M (2001) Dissolved oxygen, chlorophyll a and nutrient seasonal cycles in waters of the Gulf of Aqaba, Red Sea. Aquat Ecosys Health Manag 4(2):139-150

Blanco J (1995) Cyst production in four species of neritic dinoflagellates. J Plankton Res 17:165-182

Boney AD (1983) Phytoplanktons. Edward, Arnold Company, London

Coonley LS, Baker EB, Holland HD (1971) Iron in the Mullica River and the Great Bay, vol 7. Chemical Geology, New Jersey, pp 51-63

DOE (1991) Environmental quality standards (EQS) for Bangladesh. Department of Environment (DOE), Government of Bangladesh

Emerson K, Russo RC, Lund RE, Thurston RV (1975) Aqueous ammonia equilibrium calculations-effect of $\mathrm{pH}$ and temperature. J Fish Res Board Can 32:2379-2383

EPA Manual (1979) Methods for chemical analysis of water and wastes, EPA-600/4-79-020, Revised 3/83. Method 350:2, p. 350.2-1

Forstner H, Gnaiger E (1983) Calculation of equilibrium oxygen concentration. In: Gnaiger E, Forstner H (eds) Polarographic oxygen sensors, aquatic and physiological applications. Springer, Berlin, Heidelberg, New York, pp 321-333

Gobeil C, Sundby B, Silverberg N (1981) Factors influencing particulate matter geochemistry in the St. Lawrence turbidity maximum. Mar Chem 10:123-140

Gribsholt B, Boschker HTS, Struyf E, Andersson M, Tramper A, Brabandere LD, Damme SV, Brion N, Meire P, Dehairs F, Middelburg JJ, Heip CHR (2005) Nitrogen processing in a tidal freshwater marsh: a whole ecosystem $15 \mathrm{~N}$ labeling study. Limnol Oceanogr, 50(6)1945-1959. doi:10.4319/lo.2005.50.6.1945

Harris SA (1986) The permafrost environment. Croom Helm publ, London \& Sydney, p 276

Hoq ME, Islam ML, Paul HK, Ahmed SU, Islam MN (2002) Decomposition and seasonal changes in nutrient constituents in mangrove litter of Sundarbans mangrove, Bangladesh. Indian J Mar Sci 31(2):130-135

Hoq ME, Wahab MA, Islam MN (2006) Hydrographic status of Sundarbans mangrove, Bangladesh with special reference to post-larvae and juveniles fish and shrimp abundance. Wetlands Ecol Manage 14:79-93

Hussain Z, Acharya G (1994) Mangroves of the Sundarbans, vol 2. IUCN, Bangkok, Thailand, p 257

Ishikawa A, Taniguchi A (1994) The role of cysts on the population dynamics of Scrippsiellaspp (Dinophyceae) in Onagawa Bay, Northeast Japan. J Mar Biol 114:39-44

IWM (Institute of Water Management) (2003) Sundarbans Biodiversity Conservation Project - surface water modeling, vol 1, TA No. 3158-BAN, Final report. IWM, Dhaka, Bangladesh
Law B, Kelliher F, Baldocchi D, Anthoni P, Irvine J (2001) Spatial and temporal variation in respiration in a young ponderosa pine forest during a summer drought. Agr Forest Meteorol 110:27-43

Mitra A, Mondal K, Banerjee K (2011) Spatial and tidal variations of physico-chemical parameters in the lower Gangetic delta region, West Bengal, India. J Spat Hydro 11:52-69

Moss B (1980) Ecology of freshwaters. Blackwell Scientific Publishing, New York

Mukhopadhyay SK, Biswas H, De TK, Jana TK (2006) Fluxes of nutrients from the tropical River Hooghly at the land-ocean boundary of Sundarbans. NE Coast of Bay of Bengal, India

Nair KVK (1985) Impact of nuclear power station on the hydrobiological characteristics of Kalpakkam waters. Proceedings of the Symposium on Seawater Quality Demands held in Bombay, India, pp 13.1-13.10

NEERI (1976) Baseline water quality studies in the Hooghly Estuary. National Environmental Engineering Research Institute, Nagpur, India

Nybakken JW (1982) Marine biology: an ecological approach. Harper \& Row, Publ, New York, 446 p

PDO-ICZMP (Program Development Office for Integrated Coastal Zone Management Plan) (2005) Coastal development strategy: unlocking the potentials of the coastal zone. Draft PDO-ICZMP, Dhaka, p 116

Pliński M, Jóźwiak T (1999) Temperature and N:P ratio as factors causing blooms of blue-green algae in the Gulf of Gdańsk. Oceanologia 41(1):73-80

Rahaman SMB, Sarder L, Rahaman MS, Ghosh AK, Biswas SK, Siraj SMS, Huq KA, Hasanuzzaman AFM, Islam SS (2013) Nutrient dynamics in the Sundarbans mangrove estuarine system of Bangladesh under different weather and tidal cycles. Ecol Proc 2:29

Ramanathan AL, Subramanian V, Ramesh R, Chidambaram S, James A (1993) Environmental geochemistry of the Pichavaram mangrove ecosystem (tropical), southeast coast of India. Environ Geol 37(3):223-233

Ramesh R, Anbu M (1996) Chemical methods for environmental analysis: water and sediment. Macmillan Publishers, India Ltd, pp 15-67

Sholkovitz ER (1976) Flocculation of dissolved organic and inorganic matter during the mixing of river water and seawater. Geochim Cosmochim Acta $37: 851-880$

Siddiqi NA (2001) Mangrove forestry in Bangladesh, Institute of Forestry and Environmental Sciences. University of Chittagong, Nibedon Press Limited, Chittagong

Skinner BJ, Turekian KK (1973) Man and the ocean, Foundations of earth science series. Prentice-Hall publ, University of Virginia, p 149

Tait RV (1981) Elements of marine ecology: an introductory course, 3rd edn. Heinemann, Butterworth, p 448

Wahid SM (1995) Hydrological study of the Sundarbans, UNDP/FAO project BGD/84/056. Department of Forest, Dhaka, Bangladesh, pp 16-34

Wahid SM, Mukand SB, Bhuiyan AR (2007) Hydrologic monitoring and analysis in the Sundarbans mangrove ecosystem, Bangladesh. J Hydro 332:381-395

Weiss R (1970) The solubility of nitrogen, oxygen and argon in water and seawater. Deep Sea Res Oceanogr Abstr 17(4):721-735

William A (2002) Daily pH cycle and ammonia toxicity. World Aquaculture 34(2):20-21

Yeats PA, Bewers JM (1982) Discharge of metals from St. Lawrence River. Can J Earth Sci 19:982-992

\section{doi:10.1186/s13717-014-0018-5}

Cite this article as: Rahaman et al:: Seasonal nutrient distribution in the Rupsha-Passur tidal river system of the Sundarbans mangrove forest, Bangladesh. Ecological Processes 2014 3:18. 